\title{
An exploration study on factors influencing acceptance of electronic banking industry
}

\author{
Naser Azad*, Seyed Mohsen Seyedaliakbar, Seyedeh Soroor Mousavirad and Seyedeh Nafiseh \\ Mousavirad
}

Department of Management, Islamic Azad University, South Tehran Branch, Tehran, Iran

\begin{tabular}{l}
\hline C H R O N I C L E \\
\hline Article history: \\
Received January 18, 2013 \\
Received in revised format \\
28 April 2013 \\
Accepted 1 May 2013 \\
Available online \\
May 12013 \\
\hline Keywords: \\
Factor analysis \\
Technology acceptance \\
Banking industry \\
Electronic banking
\end{tabular}

\section{A B S T R A C T}

\begin{abstract}
This paper presents an empirical investigation to detect important factors influencing on electronic banking adoption using factor analysis. The proposed study designed a questionnaire, distributed among 210 customers who were regular customers of four banks in city of Tehran, Iran named Saderat, Eghtesad Novin, Melli and Mellat. The questionnaire consists of 42 questions and since factor analysis is sensitive on skewness of data, we have decided to remove some of the questions and summarize it into 17 questions. Cronbach alpha was calculated as 0.80 , which is well above the minimum acceptable limit and validates the results. The results of our survey indicate that four major factors including consistency, facilities, cost control and feasibility.
\end{abstract}

(c) 2013 Growing Science Ltd. All rights reserved.

\section{Introduction}

Electronic banking plays essential role in achieving electronic government. Electronic banking includes all banking services based on the implementation of electronic system. The history of electronic banking goes back to 1960s when computers were implemented in banks for the first time. The second round of electronic banking began at late 1970s named automation of the office where telecommunication services was also common in that period. The third round initiated in mid $80 \mathrm{~s}$ by connection of customers to accounts using different features such as telephone, ATM, etc. Finally, fourth period was accompanied by uniting the systems and connecting the customer to all possible banking operations. The electronic banking in Iran was initiated over the period 1981-1991 and Tejarat bank issued the first bank card in 1991 and after that Sepah bankstarted established 7 ATM stands all over the country. In 1992, Iran joined Society for Worldwide Interbank Financial Telecommunication (SWIFT) international channel and it was connected to the channel in 1993 (Rasoulian \& Safari, 2011).

\footnotetext{
*Corresponding author.

E-mail addresses: dr.naserazad@yahoo.com (N. Azad) 
Tater et al. (2011) investigated the perception of Indian customers towards the implementation of technologies with respect to such factors as convenience, privacy, security, ease of use, real time accessibility, and accurate record of varied transaction that enable customer's adoption of Banking Technology. They also examined other factors including slow transfer speed, technical failure, frauds and unawareness among customers that make hindrance in adoption. They reported that demographic variables such as gender, age, qualification and income had a positive impact in adoption of banking technology. In their survey, all the banks were using information technology as a strategic vehicle to keep competitive against other banks. There was no significant difference between adoption rates of banking technologies by the customers of various private banks. They also reported that banking technology could help in increasing customer satisfaction, customer loyalty, improvised growth, and performance of the banks.

Woherem (2000) in other investigation surveyed the impact of information technology in the Nigerian banking industry. Selamat and Jaffar (2010) performed a comprehensive investigation on effects of information technology acceptance among Malaysian Bankers. Ahmadirezaei (2011) examined the impact of information technology in one of Iranian banks called Saderat bank. He collected the necessary data from both the customers and employees at the banks. The data were analyzed using percentage and five-point Likert scale to determine the impacts of IT on the banking, objectively. The findings revealed that IT could improve bank's performance in three ways by reducing operational cost, facilitating transactions among customers within the same network and saving the time, dramatically.

Rădulescu and Serbanescu (2009) compared the types of the electronic banking services in Romania comparative with other countries and their development in the recent years. They also investigated their benefits for banks and customers, their costs and risks and their risk management. Al Nahian Riyadh et al. (2009) investigated different factors, which influence SMEs' adoption of e-banking in Bangladesh. The study came up with an integrated model including seven variables including organizational capabilities, perceived benefits, perceived credibility, perceived regulatory support, ICT industries readiness, lack of financial institutions readiness and institutional Influence, which could possibly impact the adoption of e-banking by SMEs in developing countries.

Ganguli and Roy (2011) identified the generic service quality dimensions of technology-based banking and investigated the impact of these dimensions on customer satisfaction and customer loyalty. They detected four generic service quality dimensions in the technology-based banking services - customer service, technology security and information quality, technology convenience, and technology usage easiness and reliability. They reported that customer service and technology usage easiness and reliability had positive and significant effect on customer satisfaction and customer loyalty. They also reported that technology convenience and customer satisfaction had significant and positive effect on customer loyalty.

Durkin et al. (2008) underlined the relative importance for banks to reach a customer-oriented balance between face-to-face relationship-managed activity and online enablement. Lee (2009) investigated different factors impacting the adoption of internet banking. Lee reported that the intention to implement online banking was adversely influenced mainly by the security/privacy risk, as well as financial risk and was positively influenced mainly by perceived benefit, attitude and perceived usefulness.

Pikkarainen et al. (2004) investigated consumer acceptance of online banking using an extension of the technology acceptance model. Nasri and Charfeddine (2012) performed an empirical investigation on factors influencing the adoption of Internet banking in Tunisia. They reported that Banks should improve the security and privacy to protect consumers' personal and financial information, which could increase the trust of users. Government should support banking industry by having a clear and solid law and Tunisian Banks should concentrate on those clients who already have a home PC, 
access Internet and more educated and younger since they are the most likely to adopt Internet banking.

Guriting and Ndubisi (2006) performed a study on adopting the technology acceptance model by examining the factors, which determine intention to implement online banking in Malaysia Borneo. Wang et al. (2003) introduced "perceived credibility" as a new factor, which reflects the user's security and privacy concerns in the acceptance of Internet banking. The study also examined the impact of computer self-efficacy on the intention to use Internet banking. Based on a sample of 123 users from a telephone interview, the results strongly supported the extended technology acceptance method (TAM) in forecasting the intention of users to adopt Internet banking. The survey also demonstrated the significant impact of computer self-efficacy on behavioral intention through perceived ease of use, perceived usefulness, and perceived credibility.

Anandarajan et al. (2000) performed an investigation on technology acceptance in the banking industry in a less developed country. Kolodinsky et al. (2004) performed an investigation on the adoption of electronic banking technologies by US consumers. Alsajjan and Dennis (2010) performed a cross-market investigation on internet banking acceptance. Gikandi and Bloor (2010) performed an investigation on the adoption and effectiveness of electronic banking in Kenya. Finally, Kurnia et al. (2010) did similar job on the adoption of electronic banking in China.

\section{The proposed study}

The proposed study of this paper attempts to detect important factors influencing on electronic banking industry using factor analysis. The proposed study designed a questionnaire, distributed among 210 customers who were regular customers of four banks in city of Tehran, Iran named Saderat, Eghtesad Novin, Melli and Mellat. The proposed study of this paper uses factor analysis to extract important factors. The questionnaire consists of 42 questions and since factor analysis is sensitive on skewness of data, we have decided to remove some of the questions and summarize it into 17 questions. Cronbach alpha was calculated as 0.80 , which is well above the minimum acceptable limit and validates the results. In addition, Kaiser-Meyer-Olkin Measure of Sampling Adequacy test was equal to 0.89 and Chi-Square was measured as 1671.161 , which validates the overall questionnaire. Table 1 demonstrates the results of factor analysis.

\section{Table 1}

Total Variance Explained

\begin{tabular}{|c|c|c|c|c|c|c|c|c|c|}
\hline \multirow[t]{2}{*}{ Component } & \multicolumn{3}{|c|}{ Initial Eigenvalues } & \multicolumn{3}{|c|}{ Extraction Sums of Squared Loadings } & \multicolumn{3}{|c|}{ Rotation Sums of Squared Loadings } \\
\hline & Total & $\begin{array}{c}\% \text { of } \\
\text { Variance }\end{array}$ & $\begin{array}{c}\text { Cumulative } \\
\%\end{array}$ & Total & $\begin{array}{c}\% \text { of } \\
\text { Variance }\end{array}$ & $\begin{array}{c}\text { Cumulative } \\
\%\end{array}$ & Total & $\begin{array}{c}\% \text { of } \\
\text { Variance }\end{array}$ & $\begin{array}{c}\text { Cumulative } \\
\%\end{array}$ \\
\hline 1 & 6.713 & 39.487 & 39.487 & 6.713 & 39.487 & 39.487 & 4.597 & 27.040 & 27.040 \\
\hline 2 & 1.830 & 10.762 & 50.249 & 1.830 & 10.762 & 50.249 & 3.326 & 19.563 & 46.603 \\
\hline 3 & 1.339 & 7.878 & 58.127 & 1.339 & 7.878 & 58.127 & 1.879 & 11.052 & 57.655 \\
\hline 4 & 1.112 & 6.540 & 64.667 & 1.112 & 6.540 & 64.667 & 1.192 & 7.012 & 64.667 \\
\hline 5 & .930 & 5.469 & 70.136 & & & & & & \\
\hline 6 & .747 & 4.395 & 74.531 & & & & & & \\
\hline 7 & .622 & 3.660 & 78.191 & & & & & & \\
\hline 8 & .553 & 3.255 & 81.446 & & & & & & \\
\hline 9 & .510 & 2.998 & 84.444 & & & & & & \\
\hline 10 & .472 & 2.777 & 87.221 & & & & & & \\
\hline 11 & .397 & 2.335 & 89.556 & & & & & & \\
\hline 12 & .364 & 2.139 & 91.694 & & & & & & \\
\hline 13 & .329 & 1.933 & 93.627 & & & & & & \\
\hline 14 & .315 & 1.854 & 95.481 & & & & & & \\
\hline 15 & .277 & 1.631 & 97.112 & & & & & & \\
\hline 16 & .268 & 1.575 & 98.687 & & & & & & \\
\hline 17 & .223 & 1.313 & 100.000 & & & & & & \\
\hline
\end{tabular}

Extraction Method: Principal Component Analysis. 
In addition, Table 2 shows details of our findings before and after rotation occurs.

Table 2

The results of principal component analysis before and after rotation Component Matrixa

Rotated Component Matrixa

\begin{tabular}{|c|c|c|c|c|c|c|c|c|c|}
\hline & & & onent & & & & & onen & \\
\hline & 1 & 2 & 3 & 4 & & 1 & 2 & 3 & 4 \\
\hline VAR00017 & .766 & & & & NVAR0011 & .833 & & & \\
\hline VAR00007 & .758 & & & & VAR00004 & .823 & & & \\
\hline VAR00004 & .750 & -.376 & & & VAR00026 & .780 & & & \\
\hline NVAR0011 & .747 & -.410 & & & VAR00020 & .738 & & & \\
\hline VAR00024 & .727 & & & & VAR00024 & .709 & .331 & & \\
\hline NVAR0037 & .712 & & & & NVAR0037 & .708 & & & \\
\hline VAR00020 & .672 & -.422 & & & VAR00007 & .562 & .528 & & \\
\hline VAR00036 & .650 & & -.366 & & VAR00035 & & .768 & & \\
\hline VAR00031 & .609 & & & & VAR00036 & & .731 & & -.340 \\
\hline VAR00027 & .586 & & & & VAR00034 & & .721 & & .338 \\
\hline NVAR0038 & .571 & .378 & & -.418 & NVAR0038 & & .615 & .441 & \\
\hline VAR00034 & .512 & .590 & & & VAR00031 & & .599 & & \\
\hline VAR00035 & .493 & .588 & & & VAR00027 & & .484 & & \\
\hline VAR00002 & .502 & & .609 & -.341 & VAR00003 & & & .812 & \\
\hline NVAR0006 & & & .332 & .653 & NVAR0006 & & & & .774 \\
\hline $\begin{array}{l}\text { Extraction } \mathrm{N} \\
\text { a. } 4 \text { compon }\end{array}$ & $\begin{array}{l}\text { od: } P \\
\text { extra }\end{array}$ & $m$ & alys & & $\begin{array}{l}\text { Extraction } \\
\text { Rotation } \\
\text { a. Rotation }\end{array}$ & & I & maly & \\
\hline
\end{tabular}

\section{The results}

The proposed study of this paper has determined four major factors using factor analysis and in this section, we present details of our findings.

\subsection{The first factor: Consistency}

The first factor, "consistency" includes seven components including "Usefulness", "Customer satisfaction", "Users", "Culture", "Direct payment" and "Opportunity" and the results are summarized in Table 3.

\section{Table 3}

The summary of factors associated with consistency

\begin{tabular}{|c|c|c|c|c|}
\hline Option & Factor weight & Eigenvalue & $\%$ ofvariance & Accumulated \\
\hline Usefulness & 0.833 & 6.713 & 39.487 & 39.487 \\
\hline Customer satisfaction & 0.823 & & & \\
\hline Information & 0.780 & & & \\
\hline Users & 0.738 & & & \\
\hline Culture & 0.709 & & & \\
\hline Direct payment & 0.708 & & & \\
\hline Opportunity & 0.607 & & & \\
\hline
\end{tabular}

Cronbach alph $=0.897$

It is evident from the results of Table 3 that "Usefulness" is number one priority followed by "Customer satisfaction", "Information" and "Users". Cronbach alpha has been calculated as 0.897, which validates the results of our survey.

\subsection{The second factor: Facilities}

Facilities play important role for the success of any electronic banking. This factor includes four factors including "Technology for adjusting mistakes", "Technical support", "Bank presence prevention", and "Speed" and the results of factor analysis are given in Table 4 as follows, 
Table 4

The summary of factors associated with facilities

\begin{tabular}{lcccc}
\hline Option & Factor weight & Eigenvalue & \% ofvariance & Accumulated \\
\hline Technology for adjusting mistakes & .768 & 1.830 & 10.762 & 50.249 \\
Technical support & .599 & & & \\
Bank presence prevention & .484 & & & \\
Speed & .528 & & & \\
\hline Cronbach alph $=0.709$ & & & & \\
\end{tabular}

According to the results of Table 4, "Technology for adjusting mistakes" is the most important factor followed by "Technical support", "Speed" while "“"Bank presence prevention"” comes the last priority.

\subsection{The third factor: Cost strategy}

Cost strategy is the third important factor influencing electronic banking, which includes three factors including "Cost saving", "Reduction on the number of branches", and "Competition capability". Table 5 demonstrates details of our survey where "Cost saving" plays essential role on electronic banking followed by "reduction on the number of branches".

Table 5

The summary of factors associated with cost strategy

\begin{tabular}{lcccc}
\hline Option & Factor weight & Eigenvalue & \% ofvariance & Accumulated \\
\hline Cost saving & .825 & 1.339 & 7.878 & 58.127 \\
Reduction on the number of branches & .812 & & & \\
Competition capability & .441 & & & \\
\hline Cronbach alph $=0.688$ & & &
\end{tabular}

\subsection{The fourth factor: Feasibility}

Feasibility is the last factor, which influences electronic banking and it includes three factors summarized in Table 6 as follows,

\section{Table 6}

The summary of factors associated with Feasibility

\begin{tabular}{lcccc}
\hline Option & Factor weight & Eigenvalue & $\%$ ofvariance & Accumulated \\
\hline Precision & .774 & 1.112 & 6.540 & 64.667 \\
Technology used on debit card & .340 & & & \\
The effect of government support & .338 & & & \\
\hline Cronbach alph $=0.331$ & & & & \\
\hline
\end{tabular}

Based on the results of Table 6, "Precision" is the most important factor, which influences electronic banking.

\section{Discussion and conclusion}

In this paper, we have presented an empirical investigation using principal component analysis to detect important factors influencing electronic banking. The results of our survey have revealed four major factors including consistency, facilities, cost control and feasibility. In terms of the first factor, consistency, "Usefulness" is number one priority followed by "Customer satisfaction", "Information" and "Users". In terms of the second factor, facilities, "Usefulness" is number one priority followed by "Customer satisfaction", "Information" and "Users". In terms of cost strategy, our survey indicates that "Cost saving" plays essential role on electronic banking followed by "reduction on the number of branches". Finally, in terms of feasibility, "Precision" is the most important factor influences electronic banking. 


\section{References}

Al Nahian Riyadh, M., Akter, S., \& Islam, N. (2009). The adoption of E-Banking in developing countries: A theoretical model for SMEs. International review of business research papers, 5(6), 212-230.

Alsajjan, B., \& Dennis, C. (2010). Internet banking acceptance model: cross-market examination. Journal of Business Research, 63(9), 957-963.

Ahmadirezaei, H. (2011). The effect of information technology in Saderat banking system. ProcediaSocial and Behavioral Sciences, 30, 23-26.

Anandarajan, M., Igbaria, M., \& Anakwe, U. P. (2000). Technology acceptance in the banking industry: A perspective from a less developed country. Information Technology \& People, 13(4), 298-312.

Durkin, M., Jennings, D., Mulholland, G., \& Worthington, S. (2008). Key influencers and inhibitors on adoption of the internet for banking. Journal of Retailing and Consumer Services, 15(5), 348357.

Ganguli, S., \& Roy, S. K. (2011). Generic technology-based service quality dimensions in banking: Impact on customer satisfaction and loyalty. International Journal of Bank Marketing, 29(2), 168189.

Gikandi, J. W., \& Bloor, C. (2010). Adoption and effectiveness of electronic banking in Kenya. Electronic Commerce Research and Applications, 9(4), 277-282.

Guriting, P., \& Ndubisi, N. O. (2006). Borneo online banking: evaluating customer perceptions and behavioural intention. Management Research News,29(1/2), 6-15.

Kolodinsky, J. M., Hogarth, J. M., \& Hilgert, M. A. (2004). The adoption of electronic banking technologies by US consumers. International Journal of Bank Marketing, 22(4), 238-259.

Kurnia, S., Peng, F., \& Liu, Y. R. (2010). Understanding the adoption of electronic banking in China. In System Sciences (HICSS), 2010 43rd Hawaii International Conference on (pp. 1-10). IEEE.

Lee, M. C. (2009). Factors influencing the adoption of internet banking: An integration of TAM and TPB with perceived risk and perceived benefit. Electronic Commerce Research and Applications, 8(3), 130-141.

Nasri, W., \& Charfeddine, L. (2012). Factors affecting the adoption of Internet banking in Tunisia: An integration theory of acceptance model and theory of planned behavior. The Journal of High Technology Management Research, 23(1), 1-14.

Pikkarainen, T., Pikkarainen, K., Karjaluoto, H., \& Pahnila, S. (2004). Consumer acceptance of online banking: an extension of the technology acceptance model. Internet research, 14(3), 224235.

Rasoulian, M., \& Safari, M. (2011). The reasons to lack of electronic banking achievement in Iran. International Journal of Managing Information Technology, 3(3), 51-60.

Rădulescu, M., \& Serbanescu, L. (2009). Development of the electronic banking services in Romania. Communications of the IBIMA, 8, 42-51.

Selamat, Z., \& Jaffar, N. (2010). Information Technology Acceptance: From Perspective of Malaysian Bankers. International Journal of Business and Management, 6(1), p207.

Tater, B., Tanwar, M., \& Murari, K. (2011). Customer Adoption of Banking Technology in Private Banks of India. International Journal of Banking and Finance, 8(3), 83-88.

Wang, Y. S., Wang, Y. M., Lin, H. H., \& Tang, T. I. (2003). Determinants of user acceptance of internet banking: an empirical study. International Journal of Service Industry Management, 14(5), 501-519.

Woherem, E. E. (2000). Information technology in the Nigerian banking industry. Spectrum Books Ltd. 